\title{
Defining the Relationship Between Firm's Performance and Delisting: Empirical Evidence of Going Private in Europe
}

\author{
Domitilla Magni $^{1}$ (D) Ottorino Morresi ${ }^{1}$ (D) Alberto Pezzi ${ }^{1}$. \\ Domenico Graziano² (i)
}

Received: 21 January 2021 / Accepted: 30 May 2021/Published online: 17 June 2021

(C) The Author(s), under exclusive licence to Springer Science+Business Media, LLC, part of Springer Nature, corrected publication 2021

\begin{abstract}
One of the reasons why a firm chooses to go private is the significant amount of cash flows which can exacerbate agency costs: this can indicate poor growth opportunities and make external resources less required. In line with both knowledge economy and financial literature, the paper aims to indagate the relationship between agency costs, firm's performance, and delisting. Despite there is evidence in finance that highlights the role of exchange regulators in the going private processes, just few studies focus on the voluntary delisting and its antecedents. Starting from the knowledge economy setting, this paper aims to define how firm's financial performance moderates the relationship between agency costs and delisting choices. Based on a sample of non-financial firms delisted from the most important European stock markets between 1997 and 2017, we applied an OLS regression to analyze the main variables that influence the going private processes. We find that a high level of stock market performance, associated with high level of free cash flows, promotes going private as a means of anticipating and preventing future value decreases. Finally, the paper provides practical implications for the development of new approach of delisting choice.
\end{abstract}

Keywords Delisting - Knowledge economy · Going private $\cdot$ Moderation effect . Stock return

Domitilla Magni

domitilla.magni@uniroma3.it

Extended author information available on the last page of the article 


\section{Introduction}

Over the last 20 years, the phenomenon of delisting has become more significant than Initial Public Offerings (IPOs) in terms of figures in the USA, the UK, and most stock exchanges in Continental Europe (Fidanza et al., 2018). Delisting is that process happening when a firm chooses to remove its stock from list of a regulated market (Chandy et al., 2004; Macey et al., 2008; Sanger \& Peterson, 1990).

Today, recent finance and corporate governance literature focuses much more on delisting processes, thus improving the academic and practitioner debate on the theme (Bresciani et al., 2017; Joshi et al., 2013; Sardo \& Serrasqueiro, 2017). Delisting appeared to be particularly relevant since 2000, coinciding with the collapse of the speculative tech bubble that affected many equity markets. Given the complexity and heterogeneity of delisting, it is usually useful to distinguish between voluntary and involuntary delisting (Macey et al., 2008). The voluntary delisting occurs when the parties that control the firm decide to revoke the status of a listed company; on the other hand, the exchange regulators trigger the involuntary delisting because the firm no longer has the minimum requirements to be listed. As a matter of fact, this study focuses on voluntary delisting that occurs when a firm decides to go private. We do not consider involuntary delisting which occurs when the Exchange regulator revokes the status of a listed firm because it no longer has the minimum requirements to be listed (Macey et al., 2008). Hence the interest to further investigate this phenomenon, some previous authors (Agyei-Boapeah et al., 2019; Shumway, 1997; Weir \& Wright, 2006) have analyzed if delisting could be considered as a "natural" phase in the firm's life cycle or if it is a consequence of errors committed during the design phases of the Initial Public Offering (IPO). In particular, following Lombardi et al. (2016a), we consider the modern business environment characterized by volatility and uncertainty as a further variable to be evaluated in the delisting processes. In fact, financial dynamics and knowledge economy contribute to the firm's decision-making process, even for evaluations of delisting processes as well (Ferreira et al., 2018).

In the knowledge economy setting, knowledge creates opportunity for firms who's willing to create innovative and technology long-term progresses (Gangi et al., 2019; Lombardi et al., 2016a). In this vein, financial literature we are proposing in this paper is well related to the opportunity of firms' knowledge economy in a modern business environment. Moreover, several scholars have highlighted the impact of knowledge economy on financial settings (Ahmadi \& Bouri, 2019; Du \& $\mathrm{He}, 2013$ ); while other have focused on the impact of financial variables and their effects on the firm's performance (Croci \& Giudice, 2014; He, 2008; Sung \& Choi, 2012). Alongside this, in the era of knowledge economy, very little is known about the financial variables that increase the likelihood of firm's delisting and the eventually the rapid progress of delisted firms.

This paper aims to clarify the economic and financial variables that increase the probability of delisting, providing new evidence, according to the knowledge economy, on the existing trade-off between going public and private. The paper examines how free cash flows (FCFs), and agency costs influence delisting choices. In a 
nutshell, the paper analyzes how financial performance, firm value, and stock returns moderate the relationship between FCF and delisting decisions.

Following the approach of knowledge economy, delisting process is undertaken by owner-managers in enhancing the sustainability of the firm (Del Giudice et al., 2017; Dubina et al., 2012). In this sense, by applying the lens of the micro-meso-macro level, delisting can be the trigged by the significant amount of cash flows which can exacerbate agency costs, indicate poor growth opportunities, and make external resources less required (Ahmadi \& Bouri, 2019; Lombardi et al., 2016a, b; Mouna $\&$ Anis, 2017). Moreover, very recent literature on financial performance have highlighted new evidence on the impact of corporate social responsibility knowledge on corporate financial performance (Gangi et al., 2019). In this vein, delisting processes are considerate as valid opts to achieve social responsibility performance goals and maintain high level of firms' performance (Jordão, 2017).

Starting from a review of the literature concerning FCF and agency costs (Chung et al., 2005), the study contributes to mitigate the gaps that still persist between the two theories and, through empirical analysis, to verify how FCF and agency costs influence delisting choices. Secondly, the paper analyzes the relational dynamics and the impact of the FCF on business performance, using the accounting and financial data of listed and delisted firms on the main European Stock Exchanges. Finally, the research will examine the moderation effects that exist between the FCF variable and, respectively, financial performance, firm value, and stock exchange on delisting decisions. Results show a significant and positive relationship between FCF and delisting choices. Furthermore, the moderation variables and interaction terms between financial performance and delisting are also significant. The results indicate that delisting is determined by the following factors: (i) high free cash flows, (ii) high levels of Tobin's Q on high levels of FCF, and (iii) high levels of stock returns on high levels of FCF.

The paper is organized as follows: "Literature Review" is dedicated to a review of the literature and discusses what we know about the link between FCF, agency costs, and delisting choices. "Data and Methodology" presents the design of the research project and the variables selected for the study. "Results" shows the main results, and "Conclusions" discusses and concludes.

\section{Literature Review}

Delisting occurs when a firm's stocks stop trading on a regulated stock exchange either because of the loss of minimum requirements in terms of floating, size, performance, etc., or because the firm chooses voluntarily to become a privately held company as the result of a cost-benefit analysis. Voluntary delisting is the predominant reason for delisting in the stock markets in continental Europe (Fontana et al., 2019; Leuz et al., 2008; Martinez \& Serve, 2011). Analyzing the reasons why firms decide to exit from the stock market can provide new evidence on the existing trade-off between the economic advantages of being private or remaining public. Aslan and Kumar (2011) discuss whether the decision to become public or private is an "ancient dilemma" of the stock market. Their results show that firms' specific 
characteristics can influence the delisting choices. In line with these studies, firms with high investment and financing needs, lower information production costs, and high industry market-to-book ratios are more likely to go public (Agyei-Boapeah et al., 2019; Bresciani et al., 2017; Fidanza et al., 2018).

Several studies analyze the pros and cons of delisting (Pour \& Lasfer, 2013). Chandy et al. (2004), examine the "dark side" of delisting. As soon as a firm gives up the status of a listed firm, shareholders' value and stock liquidity decrease, and managers lose prestige and visibility. In contrast, Renneboog et al. (2007) and Leuz et al. (2008) examine the potential positive implications of this phenomenon. Different firms' characteristics can motivate the decision to go private such as tax savings (Lehn \& Poulsen, 1989; Weir et al., 2005), a reduction in agency costs (due to the realignment of incentives) (He, 2008; Renneboog et al., 2007), information transfers from stakeholders to shareholders (Choi, 1991; Wright et al., 2009), direct and indirect cost reduction associated with the maintenance of listed status (Macey et al., 2008), protection from hostile takeovers through going private as a result of Management Buyouts (MBOs) (Weir \& Wright, 2006).

Moreover, Croci and Del Giudice (2014) have noticed that leaving the stock market can prove to be a favorable phenomenon due to the constant undervaluation specific firms, such as the smaller ones, experience over time.

According to the free cash flow hypothesis, the decision to delist reduces the risk that managers will invest in unprofitable projects, especially in markets that have limited growth opportunities. Furthermore, following Lee et al. (2012), knowledge management infrastructure is related to firm's knowledge process capabilities, so that providing a holistic view of knowledge management for firm's performance. This has contributed to the definition of the characteristics that a manager needs to focus on for the evaluation of the public or private firm's status (Joshi et al., 2013; Lee et al., 2012; Zack et al., 2009).

In line with the assumptions of knowledge economy (Lombardi et al., 2016a), sometimes managers may invest in projects with negative Net Present Values (NPVs) just to increase the firm's size. For that, conflicts of interest may arise when investors prefer FCFs to be distributed as dividends, rather than being stored in the firm or invested in unprofitable projects (Carayannis \& Grigoroudis, 2014; Jensen, 1986). Conflicts of interest between shareholders and managers on payout policies are significant when firms generate large cash flows. The issue is how to motivate managers to distribute cash rather than using it to finance bad projects (Carayannis \& Grigoroudis, 2014; Chung et al., 2005; Gibbs, 1993; Heaton, 2002).

A wave of delisting transactions characterized the US stock market between 1980 and 1989. Large, mature corporations with large cash flows available and poor growth opportunities decided to go private to reduce agency costs which are particularly significant in firms with fragmented ownership (Croci \& Del Giudice, 2014; Lehn \& Poulsen, 1989). Strong divergences between the interest of managers and that of shareholders triggered the choice to go private (Pagano and Röell, 1998; Fauver \& Naranjo, 2010; Del Giudice et al., 2017). 
In fulfilment of knowledge economy approach, a reason why firms decided to delist concerns the use of available cash flows (Croci \& Del Giudice, 2014; Kang, 2017). Going private allows the firm and its shareholders to have the actual availability of the cash flows produced, avoiding that they are employed in projects with negative NPV (DeAngelo et al., 1984).

Starting from this assumption, we assume that:

Hypothesis 1. FCFs and agency costs positively influence the delisting choice.

Piotroski (2000) has stated that simply observing the firm's exogenous variables may not be enough to understand delisting choice because even the historical and financial data (endogenous variables) must also be examined. Indeed, the firm's financial performance can effectively play a moderating role in delisting choices (Dickinson, 2011; Piotroski, 2000; Ritter, 1991). Management can decide to delist by not only observing the most important variables driving this choice (FCF and agency costs), but also by observing how the impact of such variables is driven by financial performance, firm value, and stock returns (Habib \& Ljungqvist, 2005; Sanger \& Peterson, 1990; Shumway, 1997).

Specially, by applying the lens of knowledge economy, Ahmadi and Bouri (2019) have noticed that operating performance can generate a very relevant impact on the delisting choices. In fact, several scholars have highlighted that high level of firm' operating performance, i.e., return on asset and return on equity measurements, propel management to delist the firm to well manage the increasing level of operating performance (Croci \& Del Giudice, 2014; Du \& He, 2013; Wright et al., 2009). Thus, starting from the knowledge economy approach, management figures out the possibility to delist firms in order to account improving levels of firms' operating performance (Weir \& Wright, 2006).

Accordingly, summarizing the above discussion, we formulate the following hypothesis:

Hypothesis 2a. Operating performance plays a moderating role between FCF and the delisting choice.

One of the most common reasons for voluntary delisting is share undervaluation (DeAngelo et al., 1984; Dickinson, 2011; Piotroski, 2000). If management believes that the true firm value exceeds its market value, it may decide to delist voluntarily. Marosi and Massoud (2007) and Kang (2017) argue that a firm's growth potential can be measured by specific financial performance variables such as operating performance, Tobin's Q, and stock returns. They argue that for a firm with a high level of performance variables, there are two options. First, it may wish to stay public to raise further financing in the market and obtain additional business opportunities in the future. Another option is that a firm may wish to go private in order to enjoy the implied growth options resulting from a high level of financial performance variables. Financial performance variables are also analyzed by examining their moderating effect on the relationship between FCF and delisting choices (DeAngelo et al., 
1984; Eberhart et al., 2004; Engel et al., 2007; Lehn \& Poulsen, 1989; Slovin et al., 1991; Smith, 1990). Finally, other scholars have provided the increasing levels of firm value as the reason why management accelerates the delisting process (Kang, 2017; Marosi \& Massoud, 2007). In this vein, Kang (2017) has noticed that Tobin's $\mathrm{Q}$ is the most suitable measure to evaluate firms' value and, for that, to be analyzed in order to assess the delisting process.

Thus, the following hypothesis is suggested:

Hypothesis $\mathbf{2 b}$. Firm value plays a moderating role between FCF and the delisting choice.

Investors always try to reward effort, commitment, and good decisions, but these variables are not perfectly observable (Gangi et al., 2019; Pour \& Lasfer, 2013). For that, starting from the knowledge economy approach, Eberhart et al. (2004) have stated that shareholders' return, i.e., stock return, could be a relevant variable in order to measure the likelihood of firm's delisting. As aforementioned, high levels of shareholder returns lead firm's management to decide to delist mainly focusing on the reasons of a best control of the firm's performance.

For that, we test the following hypothesis:

Hypothesis 2c. Shareholders' returns play a moderating role between FCF and the delisting choice.

\section{Data and Methodology}

\section{Research Design}

Three proxy variables are taken into consideration when examining agency costs (Ang et al., 2000): FCF, total asset turnover, and the operating expense ratio. We also analyze how variables such as operating performance, firm value, and stock returns moderate the relationship between FCF and probability of delisting. Figure 1 shows the research scheme.

Table 1 summarizes the set of hypotheses arising from the literature.

\section{Variables}

The dependent variable is the choice of delisting. This variable takes value 1 for delisted firms, 0 otherwise.

The independent variables are as follows:

- Agency costs:

- Free cash flow: net cash flow divided by sales.

- Total asset turnover: sales divided by total assets.

- Operating expense ratio: operating expenses divided by sales. 


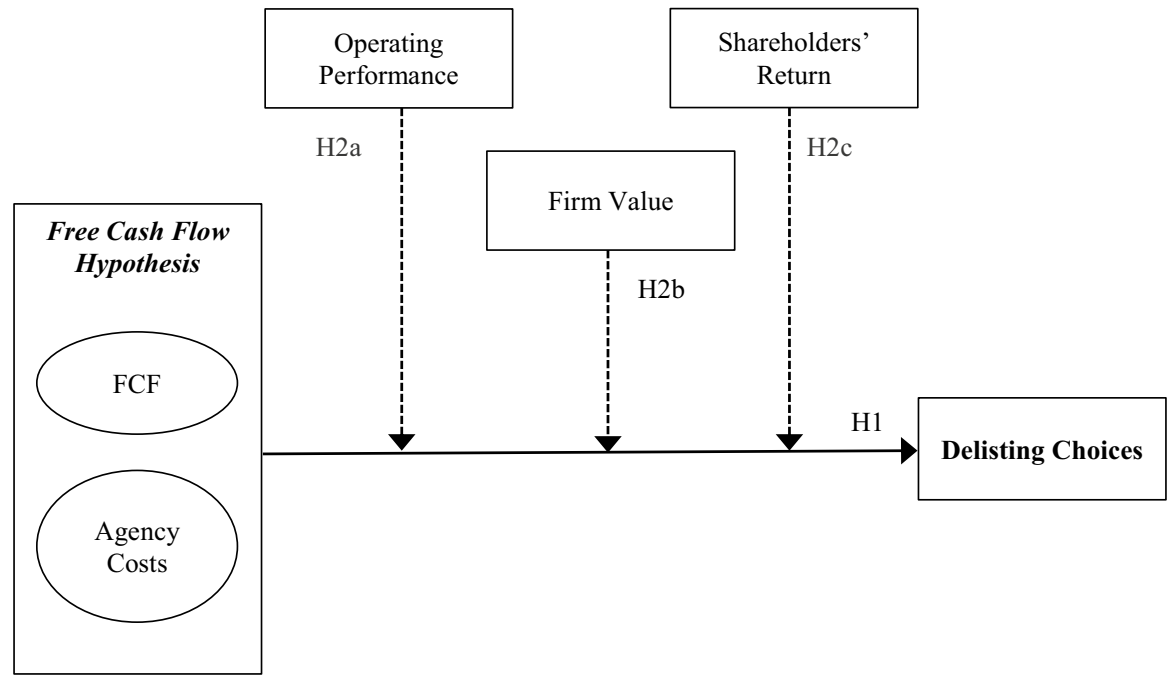

Fig. 1 Research scheme. This figure shows the research scheme hypotheses of the study. The research expected two macro research hypotheses to be evaluated: first of all, the paper wants to investigate the positive relation of free cash flow (FCF) hypothesis and agency costs on delisting (H1). Two proxy variables are taken into consideration for the agency costs: total asset turnover and operating expense ratio. Secondly, this paper intends to review the FCF assumptions and the determinants of delisting choices by analyzing moderation variables such as firm operating performance, firm value, and shareholders' returns $(\mathrm{H} 2 \mathrm{a}, \mathrm{H} 2 \mathrm{~b}, \mathrm{H} 2 \mathrm{c})$

The moderation variables are as follows:

- Operating performance: it is assumed that ROA and ROE change the intensity of the FCF-delisting relationship (Agyei-Boapeah et al., 2019).

- Firm value: Tobin's Q.

- Shareholders' returns: percentage price change of a firm's shares.

Control variables are as follows:

- Debt /total asset (DA). This variable controls for the firm's debt ratio.

- Ownership structure (Own Struct). It is a proxy for a firm's ownership dispersion (Denis \& Sarin, 1999; Hu \& Zheng, 2015; Martinez \& Serve, 2011). It is calculated as the market value of free float divided by total market value.

- Young. It describes the number of years in which the firm has been listed on the stock exchange.

- Size: natural logarithm of total assets and number of employees.

\section{Data Collection}

The sample includes non-financial firms delisted voluntarily from the main European stock exchanges between 1997 and 2017. The research analyzes the main 


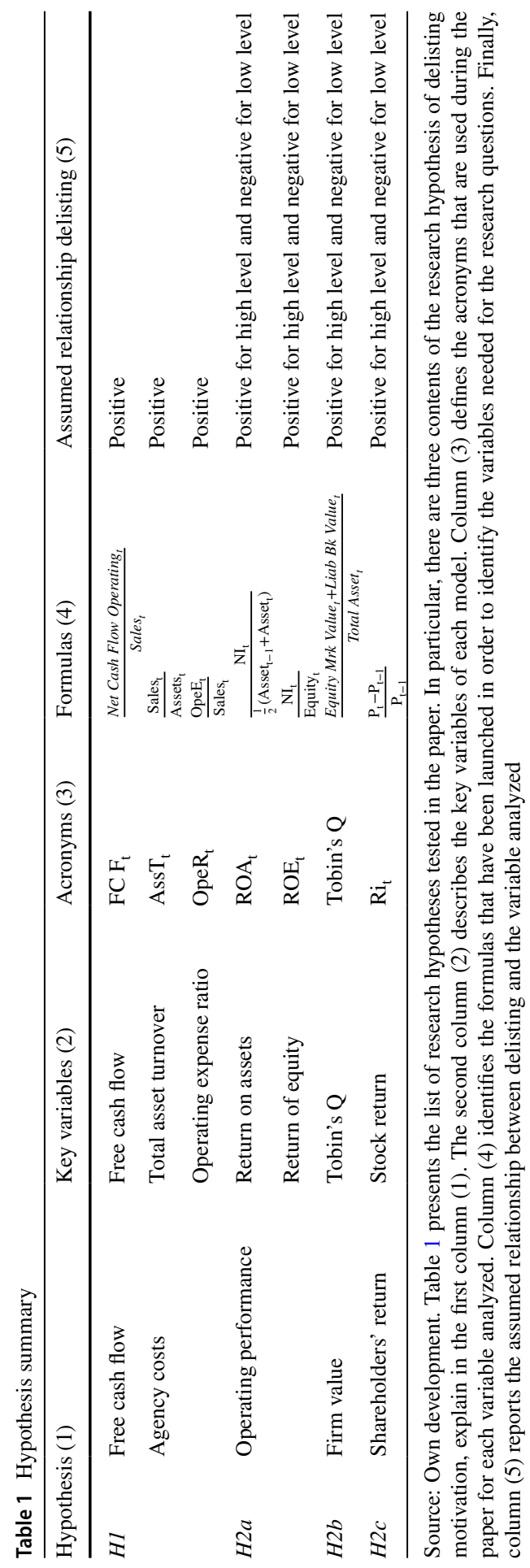


market of the London Stock Exchange, Frankfurt Stock Exchange, Milan Stock Exchange, Euronext, and other important European stock exchanges shown in Table 2. The year of delisting, company name, IPO date, and industry codes are taken from Refinitiv Datastream and Eikon (previously known as Thomson Reuters Datastream and Eikon).

A control sample is created from Refinitiv Datastream by using firms with characteristics similar to the sample of delisted firms. Initially, the sample included 2397 firms (1814 listed and 583 delisted). The control group consists of all firms in the main European stock exchanges in the same sector (SIC code) and of the same size (total assets) (Piotroski, 2000). All selected firms must have a difference in total assets in the year prior to delisting of less than $10 \%$. Variables are observed one year before delisting to mitigate possible endogenous effects.

Finally, observations with missing financial data are dropped. The final sample consists of 383 delisted firms and 609 firms for the control group (Table 2).

\section{Research Model}

Given that our dependent variable is binary and takes value 0 if the company remains listed in the period considered and 1 if the company is taken private, we have to study the probability that a certain event (i.e., delisting) occurs (i.e., $y_{i}=1$ ).

Table 2 Data sampling

\begin{tabular}{llll}
\hline Stock exchange & Control sample & Going private & \#obs \\
\hline London & 66 & 97 & 163 \\
German & 267 & 91 & 358 \\
Italy & 90 & 36 & 126 \\
France & 138 & 63 & 201 \\
Belgium & 22 & 21 & 43 \\
Portugal & 8 & 4 & 12 \\
Netherland & 14 & 21 & 35 \\
Other & 4 & 50 & 54 \\
Samples & $\mathbf{6 0 9}$ & $\mathbf{3 8 3}$ & $\mathbf{9 9 2}$ \\
\hline
\end{tabular}

Source: Own development. Table 2 presents the data sampling used in the paper. The dataset includes 992 firms from the European Stock Exchange. The observations of the sample were performed between 1997 and 2017. Moreover, the table reports the indications on the type of firms analyzed, that is non-financial firms. Column titled "Stock Exchange" reported the main Stock Exchange considered in the paper, including London Stock Exchange, Frankfurt Deutsche Borse, Borsa di Milano, and Euronext. Column "Control Sample" counts, for each Stock Exchange, the number of firms included in the control sample group. Column "Going Private" counts, for each Stock Exchange, the number of firms included in the delisting group. Finally, column "\#obs" reports the total sample size for each row and the final total sample size (992)

Data in bold represent the sample total for each respective column 
The OLS method is not appropriate because of the implicit heteroscedasticity in a qualitative response variable (Hayes \& Matthes, 2009).

For this reason, we use a Binary Logistic regression model (Harrell, 2015). The model with a binary dependent variable is outlined as follows:

$$
\begin{aligned}
& \operatorname{Pr}\left(\mathrm{Y}_{\mathrm{i}}=1 \mid \mathrm{X}_{\mathrm{i}}\right)=\mathrm{F}\left(\mathrm{X}_{\mathrm{i}} \beta\right)=\operatorname{Pr}\left(\mathrm{y}_{\mathrm{i}}^{*}>0 \mid \mathrm{X}_{\mathrm{i}}\right) \\
& \text { With } \mathrm{y}_{\mathrm{i}}^{*}=\mathrm{X}_{\mathrm{i}} \beta+\varepsilon_{i} \\
& \operatorname{Pr}\left(\mathrm{X}_{\mathrm{i}} \beta+\varepsilon_{\mathrm{i}}>0 \mid \mathrm{X}_{\mathrm{i}}\right)=\operatorname{Pr}\left(-\varepsilon_{\mathrm{i}} \leq \mathrm{X}_{\mathrm{i}} \beta \mid \mathrm{X}_{\mathrm{i}}\right)
\end{aligned}
$$

The first hypothesis is tested according to the following model:

$$
\text { delisting }_{\mathrm{t}}=\beta_{0}+\beta_{1} \text { Agency }_{\text {Costs }}+\text { Control Variables }_{\mathrm{t}}+\varepsilon_{\mathrm{t}}
$$

where agency costs is described by the following proxy variables: $\mathrm{FCF}_{t}$, Ass $\mathrm{T}_{\mathrm{t}}$, and Ope $R_{t}$. To analyze the intensity of the effects that will be found in the binary logistic regression, the values $\operatorname{Exp}(B)$ which show the effect of the variables on the odds ratio can be verified as follows:

$$
\frac{\mathrm{P}\left(\mathrm{y}_{\mathrm{i}}=1 \mid \mathrm{X}_{\mathrm{i}}\right)}{\mathrm{P}\left(\mathrm{y}_{\mathrm{i}}=0 \mid \mathrm{X}_{\mathrm{i}}\right)}
$$

To analyze the effects on the choice of delisting, the elasticity of delisting on the FCF is calculated:

$$
\text { Elasticity }=\frac{\partial \mathrm{P}\left[\mathrm{Y}_{\mathrm{i}}=1 \mid \mathrm{X}_{\mathrm{i}}\right]}{\partial \mathrm{x}_{\mathrm{i}}} \frac{\mathrm{x}_{\mathrm{i}}}{\mathrm{P}\left[\mathrm{Y}_{\mathrm{i}}=1 \mid \mathrm{X}_{\mathrm{i}}\right]}=\left(1-\mathrm{P}\left[\mathrm{Y}_{\mathrm{i}}=1 \mid \mathrm{X}_{\mathrm{i}}\right]\right) \beta_{1} \mathrm{x}_{\mathrm{i}}
$$

After verifying whether there are direct relationships between going private choices and agency costs, the research also analyzes possible moderation effects in the main model by including multiplicative terms as follows (Baron \& Kenny, 1986):

$$
\mathrm{y}_{\mathrm{i}}=\beta_{0}+\beta_{1} \mathrm{x}_{1 \mathrm{i}}+\beta_{2} \mathrm{x}_{2 \mathrm{i}}+\beta_{3} \mathrm{x}_{1 i} \mathrm{x}_{2 \mathrm{i}}+\varepsilon_{\mathrm{i}}
$$

There is a moderation effect of $x_{2 i}$ on the effect of $x_{1 i}$ on $y_{i}$ if the latter effect depends on the level of the moderation variable $x_{2 i}$, and would therefore be

$$
\frac{\partial \mathrm{y}}{\partial \mathrm{x}}=\beta_{1}+\beta_{3} \mathrm{x}_{2}
$$

We test a moderation effect of operating performance $(\mathrm{H} 2 \mathrm{a})$, firm value $(\mathrm{H} 2 \mathrm{~b})$, and stock returns $(\mathrm{H} 2 \mathrm{c})$ on the link between FCF and delisting as follows:

delisting $_{\mathrm{t}}=\beta_{0}+\beta_{1} \mathrm{FCF}_{\mathrm{t}}+\beta_{2}$ Operating Performance ${ }_{\mathrm{t}}+\beta_{3} \mathrm{FCF}_{\mathrm{t}} *$ Operating Performance $_{\mathrm{t}}+$

$$
+ \text { Control Variables }{ }_{\mathrm{t}}+\varepsilon_{\mathrm{t}}
$$




$$
\text { delisting }_{\mathrm{t}}=\beta_{0}+\beta_{1} \mathrm{FCF}_{\mathrm{t}}+\beta_{2} \text { Firm Value }{ }_{\mathrm{t}}+\beta_{3} \mathrm{FCF}_{\mathrm{t}}{ }^{*} \text { Firm Value } \mathrm{t}
$$

$$
+ \text { Control Variables }{ }_{\mathrm{t}}+\varepsilon_{\mathrm{t}}
$$

delisting $_{\mathrm{t}}=\beta_{0}+\beta_{1} \mathrm{FCF}_{\mathrm{t}}+\beta_{2}$ Stock Return $_{\mathrm{t}}+\beta_{3} \mathrm{FCF}_{\mathrm{t}}{ }^{*}$ Stock Return $_{\mathrm{t}}+$ Control Variables ${ }_{\mathrm{t}}+\varepsilon_{\mathrm{t}}$

\section{Results}

Table 3 reports the number of observations $(\mathrm{N})$, mean (Mean), standard deviation (StdDev), minimum (Min), and maximum (Max) for the variables in the full sample (Panel A), control sample (Panel B), and delisted firms (Panel C).

The correlations between all independent and control variables are calculated to find potential multicollinearity problems (Table 4).

The first binary logistic regression model (Table 5, model 1) analyzes the direct relationship between FCF and delisting. FCF shows a positive and significant influence on the choice of going private.

The intensity of the effect of FCF on delisting choices is calculated using the $\operatorname{Exp}(\mathrm{B})$ column. In this case, a unit increase in FCF increases the odds ratio of 6.179. The elasticity calculated to estimate the effects of FCF on delisting choices is equal to 0.20 . This means that, on average, a one percent-point increase in FCF increases the probability of delisting by $0.20 \%$.

Nagelkerke's $R^{2}$ shows a value equal to 0.243 , while that of McFadden is 0.159 . Finally, the hit ratio measures $82.2 \%$, a value much higher than $50 \%$, a value that is acceptable compared to the random choice between two values (Cox, 2018).

The second and third models (Table 5, model 2 and 3) do not show significant results in relation to the impact of total asset turnover and the operating expense ratio on going private choices.

Tables 6 and 7 test the postulated hypotheses on the moderation effects and show how the effect of FCF on delisting choices is substantially mitigated and moderated by financial performance variables. In particular, we explicit the effects of financial performance variables for both high level (HL) and low level (LL).

Moderation terms allow us to study how much the effect of an independent variable changes as the levels of another variable change which, in our case, are variables describing the operational and financial performance of a firm. The interaction effect indicates how strongly the moderator conditions the main effect.

The results show significant, positive effects for a high level of stock market variables (Table 7) and negative and significant effects for a low level of the same variables. Thus, the effect of FCF on delisting choices decreases with a low level of financial performance moderation variables and increases with a high level of financial performance moderation variables. Following this perspective, firms with high levels of stock market performance may wish 
Table 3 Descriptive statistics

\begin{tabular}{|c|c|c|c|c|c|}
\hline & \#obs & Mean & StdDev & Min & Max \\
\hline \multicolumn{6}{|c|}{ Panel A-All firms } \\
\hline FCF & 854 & 19.96 & 482.36 & -151.29 & $13,650.72$ \\
\hline AssT & 854 & 1.02 & 1.26 & -0.02 & 32.49 \\
\hline OpeR & 759 & 1.71 & 18.14 & -5.30 & 495.86 \\
\hline ROA & 858 & 2.65 & 12.79 & -141.45 & 75.92 \\
\hline ROE & 846 & 2.95 & 72.34 & -483.57 & 1512.18 \\
\hline Tobin's Q & 948 & 262.45 & 8036.91 & 0.00 & $247,454.73$ \\
\hline Stock return & 911 & 0.07 & 0.45 & -3.50 & 8.97 \\
\hline $\mathrm{DA}$ & 863 & 22.95 & 18.84 & 0.00 & 167.52 \\
\hline Own structure & 849 & 0.59 & 0.28 & 0.00 & 2.52 \\
\hline Employees & 840 & $15,339.7$ & $46,861.33$ & 0.00 & 483,598 \\
\hline Ln TA & 992 & 13.17 & 2.64 & 6.66 & 23.65 \\
\hline Young & 992 & 19.30 & 5.13 & 4 & 38 \\
\hline \multicolumn{6}{|c|}{ Panel B-Firms from control group } \\
\hline FCF & 605 & -0.19 & 6.44 & -151.29 & 1.40 \\
\hline Ass T & 594 & 1.06 & 1.44 & -0.02 & 32.49 \\
\hline OpeR & 514 & 0.95 & 0.23 & 0.06 & 3.40 \\
\hline ROA & 609 & 2.67 & 12.29 & -141.45 & 61.05 \\
\hline ROE & 609 & 3.27 & 81.23 & -483.57 & 1512.18 \\
\hline Tobin's Q & 609 & 408.13 & $10,027.29$ & 0.35 & $247,454.73$ \\
\hline Stock return & 532 & 0.13 & 0.44 & -0.33 & 8.97 \\
\hline DA & 609 & 22.34 & 17.15 & 0.00 & 100.1 \\
\hline Own structure & 527 & 0.62 & 0.23 & 0.01 & 1.13 \\
\hline Employees & 604 & $14,686.21$ & $47,724.52$ & 0.00 & 483,598 \\
\hline Ln TA & 609 & 13.44 & 2.47 & 7.91 & 19.01 \\
\hline Young & 609 & 18.40 & 2.56 & 4 & 21 \\
\hline \multicolumn{6}{|c|}{ Panel C-Delisted firms } \\
\hline $\mathrm{FCF}$ & 249 & 64.01 & 869.42 & -8.28 & $13,650.72$ \\
\hline AssT & 260 & 0.93 & 0.70 & 0.0003 & 3.69 \\
\hline OpeR & 245 & 3.29 & 31.91 & -5.30 & 495.86 \\
\hline ROA & 249 & 2.57 & 13.98 & -82.86 & 75.92 \\
\hline ROE & 237 & 2.12 & 41.67 & -256.25 & 194.95 \\
\hline Tobin's Q & 339 & 0.74 & 0.99 & 0.00 & 7.17 \\
\hline Stock return & 379 & -0.008 & 0.44 & -3.50 & 1.00 \\
\hline DA & 254 & 24.40 & 22.34 & 0.00 & 167.52 \\
\hline Own structure & 358 & 0.54 & 0.35 & 0.00 & 2.52 \\
\hline Employees & 236 & $17,012.19$ & $44,630.95$ & 0 & 362,000 \\
\hline $\mathrm{Ln} \mathrm{TA}$ & 383 & 12.75 & 2.84 & 6.66 & 23.65 \\
\hline Young & 383 & 20.75 & 7.37 & 4 & 38 \\
\hline
\end{tabular}

Source: Own development. Table 3 presents descriptive statistics of the following firm variables: free cash flow (FCF), total asset turnover (AssT), operating expense ratio (OpeR), ROA, ROE, Tobin's Q, stock return, debt scaled by asset (DA), ownerships structure (Own Structure), number of employees (Employees), firm's size explained as natural logarithm of Total Assets (Ln TA), and the number of years in which firms preside over the Stock Exchange (Young). The table reports the number of observations, 
Table 3 (continued)

mean, standard deviation, minimum, and maximum for each variable. This table also outlines the specific sample for each research panel: in particular, panel A examines all the descriptive variables for the total firms' sample. Panel B reports the results of the descriptive analysis on the sample of control group firms. Finally, panel $\mathrm{C}$ describes the results inherent to the survey group of delisted firms

to delist in order to enjoy the implied growth options resulting from these consequences.

In more detail, Tobin's Q moderates the direct and positive effect of FCFs on delisting when Tobin's $Q$ value is low, and vice versa. The same moderation effect can be found for stock returns. Indeed, by inserting the moderation variable in the model, the interactive effect between FCF and stock market variables is significant and positive which means that when FCFs are high, accompanied with high levels of Tobin's Q or stock returns, the firm increases the probability of delisting. Low levels of Tobin's Q or stock returns reduce the probability of delisting associated with FCF.

Finally, Table 8 summarizes the research hypotheses, the key variables, and the relationships assumed between the variables and those observed.

\section{Discussion and Implications}

The results indicate that delisting on the most important European stock exchanges is determined by the following factors: (i) high volumes of free cash flows, (ii) high levels of Tobin's Q as a moderating effect, and (iii) high levels of stock returns as a moderating effect.

So as, starting from the knowledge economy approach, firm-specific variables such as Firm Value and Stock Return are moderating variables to analyze delisting choices. Moreover, results show that the availability of FCF is the most relevant element to evaluate delisting decision (Croci \& Del Giudice, 2014; Kang, 2017). Our results are in line with previous studies (Bresciani et al., 2017; Kang, 2017; Lombardi et al., 2016a, b; Sardo \& Serrasqueiro, 2017), thus, higher level of FCF determines and higher likelihood of delisting. Therefore, it can be deduced that the direct effects of free cash flow and the moderating effects of financial variables are the central axes of delisting choice in the European stock exchange. In other words, the choice of delisting originates in the moderation intensity of typical corporate and financial variables on the free cash flow assumptions (Fontana et al., 2019; Leuz et al., 2008). High FCFs cause firms to go private in order to cope with higher agency costs that could deteriorate firm performance. Indeed, we also find that a good stock market performance, associated with high FCFs, promotes going private as a means of anticipating and preventing future value decreases. The presence of some agency problems induces the firm to exit the stock market before such problems can harm firm value. Actually, there is a twofold explanation for the delisting choices: first, when all the moderation variables 


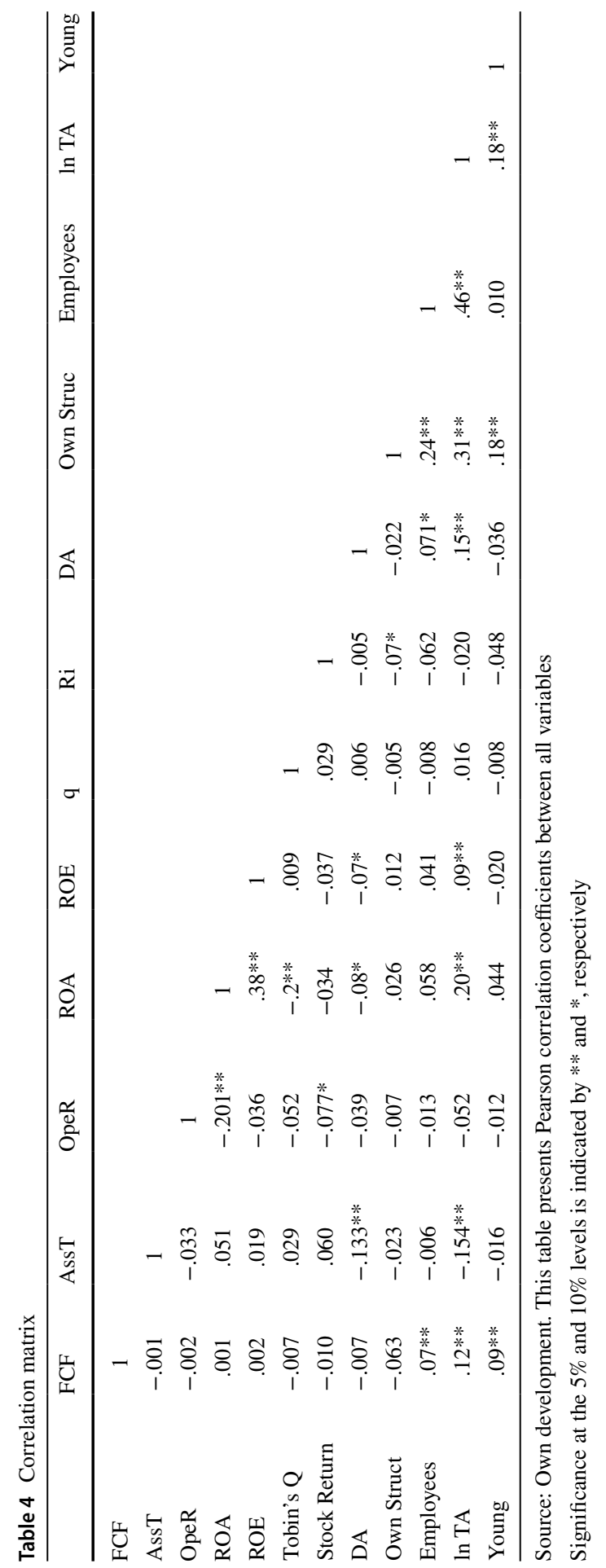


Table 5 Results of hypotheses tests. The effect of FCF and agency costs on delisting choices

\begin{tabular}{|c|c|c|c|c|c|c|c|}
\hline \multirow[t]{2}{*}{ Type of variable } & \multirow[t]{2}{*}{ Variables } & \multicolumn{2}{|l|}{ Model 1} & \multicolumn{2}{|l|}{ Model 2} & \multicolumn{2}{|l|}{ Model 3} \\
\hline & & B & $\operatorname{Exp}(B)$ & B & $\operatorname{Exp}(B)$ & B & $\operatorname{Exp}(B)$ \\
\hline & Constant & -2.221 & .109 & $-2.705^{* * *}$ & .067 & $-2.729 * * *$ & .065 \\
\hline \multirow[t]{3}{*}{ Independent } & FCF & $1.821 * * *$ & 6.179 & & & & \\
\hline & AssT & & & -.069 & .933 & & \\
\hline & OpeR & & & & & .067 & 1.069 \\
\hline \multirow[t]{5}{*}{ Control } & DA & .004 & 1.004 & .007 & 1.007 & $.010 * *$ & 1.010 \\
\hline & Own Struct & .325 & 1.384 & -.052 & .949 & -.050 & 9.51 \\
\hline & Employees & .000 & 1.000 & .000 & 1.000 & .000 & 1.000 \\
\hline & $\ln \mathrm{TA}$ & $-.183 * * *$ & .833 & $-.116^{* * *}$ & .890 & $-.13 * * *$ & .876 \\
\hline & Young & $.147 * * *$ & 1.159 & $.160 * * *$ & 1.174 & $.167 * * *$ & 1.182 \\
\hline Mc Fadden $\mathrm{R}^{2}$ & & .159 & & .090 & & .107 & \\
\hline Nagelkerke $\mathrm{R}^{2}$ & & .243 & & .146 & & .174 & \\
\hline Hit Ratio & & 82.2 & & 81.2 & & 81.3 & \\
\hline Elasticity & & .020 & & & & & \\
\hline
\end{tabular}

Source: Own development. Table 5 presents coefficient estimates and $\operatorname{Exp}(\mathrm{B})$ for the first research hypothesis's model regressions. The dependent variable, yit, is dummy variable "delisting" which assumes two different values: 1 for delisted firms and 0 for no-delisted firms. In the first binary logistic regression (Model 1), the intensity of the FCF's effect on delisting choices are calculated by looking at the $\operatorname{Exp}(\mathrm{B})$ column. DA, Own Struct, Employees, In TA, and Young are control variables. Models 2 and 3 report coefficient estimates and $\operatorname{Exp}(\mathrm{B})$ for the second research hypothesis. The second and third binary logistic regressions do not find significant parameters to evaluate the impact of the Total Asset Turnover (AssT and OpeR) on going private choices

Significance at the $1 \%$ and $5 \%$ levels is indicated by $* * *$ and $* *$, respectively

are high, then this determines a high probability of going private; second, when the direct variable of FCFs is high, then this also determines a high probability of going private. In the first case, high levels of financial performance followed by high levels of free cash flow cause management to behave opportunistically (Chen et al., 2012; McKnight \& Weir, 2009; Sitkoff, 2003) and this leads to delisting choices. In the second case, however, high levels of free cash flow linked to low levels of financial variables (as moderators), lead to a decrease in the probability of delisting due to the reputation issue (Martinez \& Serve, 2011). As a matter of fact, well-performing firms that do not need external resources find that it is pointless to remain listed on the stock market given the risks posed by high FCFs. In this knowledge economy context, our results convey to the literature and to the main assumptions of FCFs and firm's performance hypotheses. 


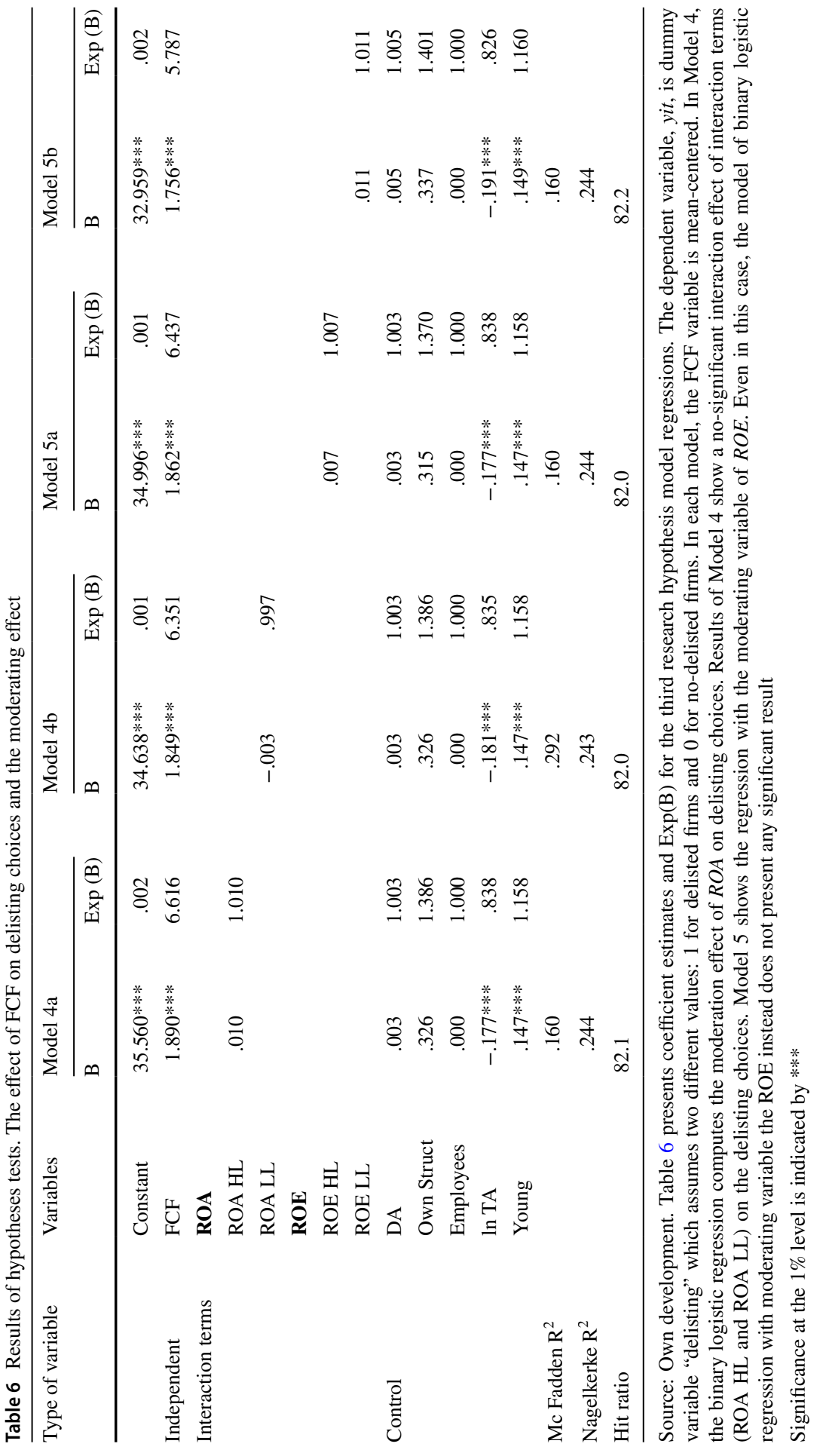




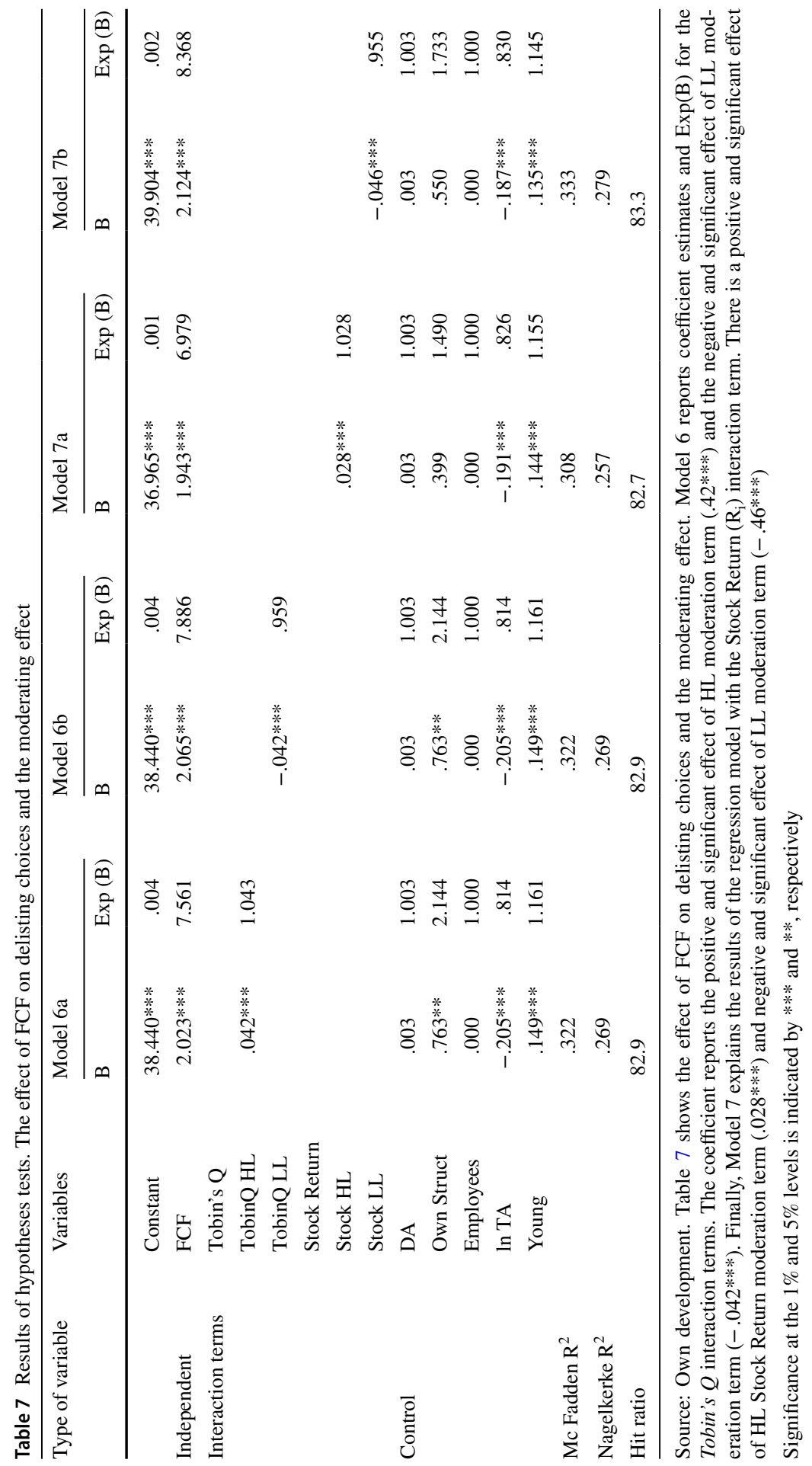




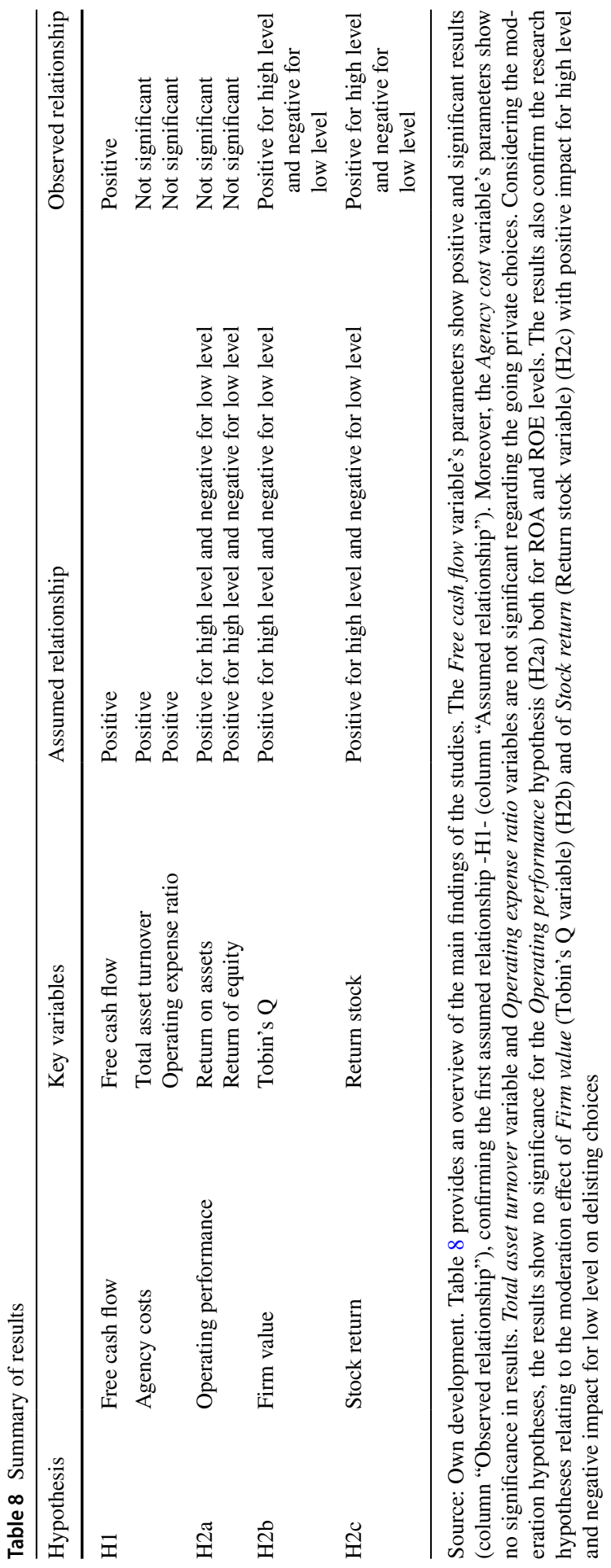




\section{Conclusions}

The paper shows that delisting of firms listed on the most important European stock exchanges is mainly due to FCF and financial moderation variables i.e., Tobin's Q and Stock Return. The availability of FCF is the main direct factor in delisting decisions.

Our results guide for further studies and surveys on the subject, in both academic and capital market implications, and act as warning signs for investors, to assess and forestall the likelihood that firms listed may decide to delist.

One of the main limitations of delisting research is the availability of post-delisting data. This is a specific characteristic of this type of study since the firm no longer desires sharing information with the market after delisting choice. In addition to that, we underline that the study focuses on the analysis of firms' intrinsic factors, thus less on the analysis of business environmental factors. For future research, we can suggest to better detect the environmental elements, even regarding the impact of COVID-19 on the stock market, which is believed to have influenced delisting.

\section{References}

Agyei-Boapeah, H., Wang, Y., Tunyi, A. A., Machokoto, M., \& Zhang, F. (2019). Intangible investments and voluntary delisting: Mass exodus of Chinese firms from US stock exchanges. International Journal of Accounting \& Information Management, 27(2), 224-243.

Ahmadi, A., \& Bouri, A. (2019). The effect of audit quality on the extent of voluntary disclosure: Companies listed in the Tunisian Stock Exchange. Journal of the Knowledge Economy, 10(1), 59-73.

Ang, J. S., Cole, R. A., \& Lin, J. W. (2000). Agency costs and ownership structure. The Journal of Finance, 55(1), 81-106.

Aslan, H., \& Kumar, P. (2011). Lemons or cherries? Growth opportunities and market temptations in going public and private. Journal of Financial and Quantitative Analysis, 489-526.

Baron, R. M., \& Kenny, D. A. (1986). The moderator-mediator variable distinction in social psychological research: Conceptual, strategic, and statistical considerations. Journal of Personality and Social Psychology, 51(6), 1173.

Bresciani, S., Del Giudice, M., \& Papa, A. (2017). Public control and strategic governance in state-owned public utilities: Empirical evidence from Italian listed firms. Sinergie Italian Journal of Management, 35(1), 47-64.

Carayannis, E., \& Grigoroudis, E. (2014). Linking innovation, productivity, and competitiveness: Implications for policy and practice. The Journal of Technology Transfer, 39(2), 199-218.

Chandy, P. R., Sarkar, S. K., \& Tripathy, N. (2004). Empirical evidence on the effects of delisting from the national market system. Journal of Economics and Finance, 28(1), 46-55.

Chen, C. X., Lu, H., \& Sougiannis, T. (2012). The agency problem, corporate governance, and the asymmetrical behavior of selling, general, and administrative costs. Contemporary Accounting Research, 29(1), 252-282.

Choi, D. (1991). Toehold acquisitions, shareholder wealth, and the market for corporate control. Journal of Financial and Quantitative Analysis, 26(3), 391-407.

Chung, R., Firth, M., \& Kim, J. B. (2005). FCF agency costs, earnings management, and investor monitoring. Corporate Ownership and Control, 2(4), 51-61.

Cox, D. R., (2018). Analysis of survival data. Chapman and Hall/CRC.

Croci, E., \& Giudice, A. D. (2014). Delistings, controlling shareholders and firm performance in Europe. European Financial Management, 20(2), 374-405.

DeAngelo, H., DeAngelo, L., \& Rice, E. M. (1984). Going private: Minority freezeouts and stockholder wealth. The Journal of Law and Economics, 27(2), 367-401.

Del Giudice, M., Khan, Z., De Silva, M., Scuotto, V., Caputo, F., \& Carayannis, E. (2017). The microlevel actions undertaken by owner-managers in improving the sustainability practices of cultural and 
creative small and medium enterprises: A United Kingdom-Italy comparison. Journal of Organizational Behavior, 38(9), 1396-1414.

Denis, D. J., \& Sarin, A. (1999). Ownership and board structures in publicly traded corporations. Journal of Financial Economics, 52(2), 187-223.

Dickinson, V. (2011). Cash flow patterns as a proxy for firm life cycle. The Accounting Review, 86(6), 1969-1994.

Du, J., \& He, Q. (2013). Tunneling and the decision to go private: Evidence from Hong Kong. PacificBasin Finance Journal, 22, 50-68.

Dubina, I. N., Carayannis, E. G., \& Campbell, D. F. (2012). Creativity economy and a crisis of the economy? Coevolution of knowledge, innovation, and creativity, and of the knowledge economy and knowledge society. Journal of the Knowledge Economy, 3(1), 1-24.

Eberhart, A. C., Maxwell, W. F., \& Siddique, A. R. (2004). An examination of long-term abnormal stock returns and operating performance following R\&D increases. The Journal of Finance, 59(2), 623-650.

Engel, E., Hayes, R. M., \& Wang, X. (2007). The Sarbanes-Oxley Act and firms' going-private decisions. Journal of Accounting and Economics, 44(1-2), 116-145.

Fauver, L., \& Naranjo, A. (2010). Derivative usage and firm value: The influence of agency costs and monitoring problems. Journal of Corporate Finance, 16(5), 719-735.

Ferreira, J., Mueller, J., \& Papa, A. (2018). Strategic knowledge management: Theory, practice and future challenges. Journal of Knowledge Management, 24(2), 121-126.

Fidanza, B., Morresi, O., \& Pezzi, A. (2018). The decision to delist from the Stock Market Theory and Empirical Evidence of Going Private. Springer.

Fontana, S., Coluccia, D., \& Solimene, S. (2019). VAIC as a tool for measuring intangibles value in voluntary multi-stakeholder disclosure. Journal of the Knowledge Economy, 10(4), 1679-1699.

Gangi, F., Mustilli, M., \& Varrone, N. (2019). The impact of corporate social responsibility (CSR) knowledge on corporate financial performance: Evidence from the European banking industry. Journal of Knowledge Management, 23(1), 110-134.

Gibbs, P. A. (1993). Determinants of corporate restructuring: The relative importance of corporate governance, takeover threat, and free cash flow. Strategic Management Journal, 14(S1), 51-68.

Habib, M. A., \& Ljungqvist, A. (2005). Firm value and managerial incentives: A stochastic frontier approach. The Journal of Business, 78(6), 2053-2094.

Harrell, F. E. (2015). Ordinal logistic regression, in Regression modeling strategies (pp. 311-325). Springer.

Hayes, A. F., \& Matthes, J. (2009). Computational procedures for probing interactions in OLS and logistic regression: SPSS and SAS implementations. Behavior Research Methods, 41(3), 924-936.

He, L. (2008). Do founders matter? A study of executive compensation, governance structure and firm performance. Journal of Business Venturing, 23(3), 257-279.

Heaton, J. B. (2002). Managerial optimism and corporate finance. Financial Management, 31(2), 33-45.

Hu, D., \& Zheng, H. (2015). Does ownership structure affect the degree of corporate financial distress in China? Journal of Accounting in Emerging Economies, 5(1), 35-50.

Jensen, M. C. (1986). Agency costs of free cash flow, corporate finance, and takeovers. The American Economic Review, 76(2), 323-329.

Jordão, R. V. D. (2017). Performance measurement, intellectual capital and financial sustainability. Journal of Intellectual Capital, 18(3), 643-666.

Joshi, M., Cahill, D., Sidhu, J., \& Kansal, M. (2013). Intellectual capital and financial performance: An evaluation of the Australian financial sector. Journal of Intellectual Capital, 14(2), 264-285.

Kang, S. M. (2017). Voluntary delisting in Korea: Causes and impact on company performance. Journal of Applied Business Research (JABR), 33(2), 391-408.

Lee, S., Kim, B. G., \& Kim, H. (2012). An integrated view of knowledge management for performance. Journal of Knowledge Management, 16(2), 183-203.

Lehn, K., \& Poulsen, A. (1989). Free cash flow and stockholder gains in going private transactions. The Journal of Finance, 44(3), 771-787.

Leuz, C., Triantis, A., \& Wang, T. Y. (2008). Why do firms go dark? Causes and economic consequences of voluntary SEC deregistrations. Journal of Accounting and Economics, 45(2), 181-208.

Lombardi, R., Coluccia, D., Russo, G., \& Solimene, S. (2016a). Exploring financial risks from corporate disclosure: Evidence from Italian listed companies. Journal of the Knowledge Economy, 7(1), 309-327. 
Lombardi, R., Del Giudice, M., Caputo, A., Evangelista, F., \& Russo, G. (2016b). Governance and assessment insights in information technology: The Val IT model. Journal of the Knowledge Economy, 7(1), 292-308.

Macey, J., O’Hara, M., \& Pompilio, D. (2008). Down and out in the stock market: The law and economics of the delisting process. The Journal of Law and Economics, 51(4), 683-713.

Marosi, A., \& Massoud, N. (2007). Why do firms go dark? Journal of Financial and Quantitative Analysis, 42(2), 421-442.

Martinez, I., \& Serve, S. (2011). The delisting decision: The case of buyout offer with squeeze-out (BOSO). International Review of Law and Economics, 31(4), 228-239.

McKnight, P. J., \& Weir, C. (2009). Agency costs, corporate governance mechanisms and ownership structure in large UK publicly quoted companies: A panel data analysis. The Quarterly Review of Economics and Finance, 49(2), 139-158.

Mouna, A., \& Anis, J. (2017). Stock market, interest rate and exchange rate risk effects on non financial stock returns during the financial crisis. Journal of the Knowledge Economy, 8(3), 898-915.

Pagano, M., \& Roell, A. (1998). The choice of stock ownership structure: Agency costs, monitoring and the decision to go public. Quarterly Journal of Economics, 113, 187-225.

Piotroski, J. D. (2000). Value investing: The use of historical financial statement information to separate winners from losers. Journal of Accounting Research, 38, 1-41.

Pour, E. K., \& Lasfer, M. (2013). Why do companies delist voluntarily from the stock market? Journal of Banking \& Finance, 37(12), 4850-4860.

Renneboog, L., Simons, T., \& Wright, M. (2007). Why do public firms go private in the UK? The impact of private equity investors, incentive realignment and undervaluation. Journal of Corporate Finance, 13(4), 591-628.

Ritter, J. R. (1991). The long-run performance of initial public offerings. The Journal of Finance, 46(1), 3-27.

Sanger, G. C., \& Peterson, J. D. (1990). An empirical analysis of common stock delistings. Journal of Financial and Quantitative Analysis, 25(2), 261-272.

Sardo, F., \& Serrasqueiro, Z. (2017). A European empirical study of the relationship between firms' intellectual capital, financial performance and market value. Journal of Intellectual Capital, 18(4), $771-788$.

Shumway, T. (1997). The delisting bias in CRSP data. The Journal of Finance, 52(1), 327-340.

Sitkoff, R. (2003). An agency costs theory of trust law. working paper, Cornell L. Rev, Northwestern Univeristy, September, 89, 621.

Slovin, M. B., Sushka, M. E., \& Bendeck, Y. M. (1991). The intra-industry effects of going-private transactions. The Journal of Finance, 46(4), 1537-1550.

Smith, A. J. (1990). Corporate ownership structure and performance: The case of management buyouts. Journal of Financial Economics, 27(1), 143-164.

Sung, S. Y., \& Choi, J. N. (2012). Effects of team knowledge management on the creativity and financial performance of organizational teams. Organizational Behavior and Human Decision Processes, $118(1), 4-13$.

Weir, C., \& Wright, M. (2006). Governance and takeovers: Are public-to-private transactions different from traditional acquisitions of listed corporations? Accounting and Business Research, 36(4), 289-307.

Weir, C. M., Laing, D., \& Wright, M. (2005). Undervaluation, private information, agency costs and the decision to go private. Applied Financial Economics, 15, 947-961.

Wright, M., Amess, K., Weir, C., \& Girma, S. (2009). Private equity and corporate governance: Retrospect and prospect. Corporate Governance: An International Review, 17(3), 353-375.

Zack, M., McKeen, J., \& Singh, S. (2009). Knowledge management and organizational performance: An exploratory analysis. Journal of Knowledge Management, 13(6), 392-409.

Publisher's Note Springer Nature remains neutral with regard to jurisdictional claims in published maps and institutional affiliations. 


\section{Authors and Affiliations}

\section{Domitilla Magni $^{1}$ (D) Ottorino Morresi ${ }^{1}$ (D) Alberto Pezzi ${ }^{1}$.}

\section{Domenico Graziano ${ }^{2}$ (ID}

Ottorino Morresi

ottorino.morresi@uniroma3.it

Alberto Pezzi

alberto.pezzi@uniroma3.it

Domenico Graziano

domenico.graziano@unicampania.it

1 Department of Business Studies, Roma Tre University, Via Silvio D’Amico 77, 00145 Rome, Italy

2 Department of Economics, University of Campania Luigi Vanvitelli, Corso Gran Priorato Di Malta, 81043 Capua, Italy 